\title{
A rheological comparison of hard grade binders with polymer modified bitumen under aged and unaged conditions
}

\author{
I. Hafeez \& M. A. Kamal \\ Department of Civil Engineering, \\ University of Engineering and Technology, Pakistan
}

\begin{abstract}
High ambient temperature and uncontrolled heavy axle loads are considered to be the root cause of premature failure of flexible pavements, especially rutting, in Pakistan. In order to combat rutting problems, 60/70 penetration grade bitumen modified with Elvaloy Terpolymer (PMB) has been used on various critical sections since 2001. Rheological characteristics of PMB, 60/70 and 40/50 penetration grade bitumen were studied using a dynamic shear rheometer at 25 , 40 and $55^{\circ} \mathrm{C}$. Short term aging effects were also studied in a rolling thin film oven test and the results of aged and unaged binders have been compared. The study revealed that the complex shear modulus of binders reduces significantly with an increase in temperature, while the phase angle increases, but at a lesser rate. Short term aging has showed relatively less influence on binder rheology than temperature.
\end{abstract}

Keywords: rheology, bitumen, aging, temperature.

\section{Introduction}

Pakistan has a total road network of 258,340 kilometers comprising 165,762 km of high type roads and $92,578 \mathrm{~km}$ of low type roads. The length of high type roads has increased by 40 percent since 1995-96 [1]. Over the past twenty years, road traffic (both passenger and freight) has grown significantly and loading is getting progressively worse due to the import of more powerful trucks with heavier wider bodies in Pakistan. One of the probable factors of increased road traffic is the decreased trend in railway use during the recent past. Consequently, 
premature rutting in the form of shear flow in flexible pavements has been observed due to high ambient temperatures. The National Highway Authority (NHA), Pakistan, has been facing serious threats, such as frequent pavement failures, poor riding quality and high maintenance costs. Modifications of bitumen with polymers and the adoption of rigid pavement construction have increased the construction cost compared to that of conventional pavements. Among the other factors causing the premature failure of the flexible pavements, the properties of binders are believed to be the most important parameter. In order to cater for the growing axle load and to increase the performance of bituminous mixes, it is necessary to investigate the true prediction and evaluation of binder rheological parameters in parallel.

\section{Literature review}

Rheology is the study of the deformation and flow of bitumen that explains the elastic and viscous behavior of bitumen when subjected to a stress [2, 3]. Complex modulus $\left(\mathrm{G}^{*}\right)$ and phase angle $(\delta)$ are considered to be the principal rheological parameters, normally measured from a device known as Dynamic Shear Rheometer (DSR) [4]. The complex modulus is the peak-to-peak shear stress to absolute value of peak-to-peak shear strain and the phase angle is the angle in radian between a simultaneously applied stress and the resulting sinusoidal stress in a controlled strain testing mode [5].

A number of researches have reported on binder rheology in the past, but little information is available regarding the effects of polymers on binder rheology at different temperatures under aged and unaged conditions. Branthaver et al. [6] reported that a reduction in the weight and quantity of the non-polar molecules occurs under aging phenomenon, which is due to conversion of non-polar molecules to the polar carbonyl group. They further concluded that new polar sites will form association with other polar molecules, making the bitumen molecules, to which they attached; act as strong polar associating molecules.

It has been reported by Hunter [7] that the rutting tendency of a pavement is greatly influenced by the ratio of the complex modulus to the phase angle. In order to maximize the rutting parameters, a high value of ' $G$ *' and low values of ' $\delta$ ' are required. In order to reduce the fatigue parameters, a low value of ' $\mathrm{G}^{*}$ ' and ' $\delta$ ' are required.

Tarefder et al. [8] investigated the most important factors affecting the rutting and performance grade (PG) of bitumen and determined that specimen type, test temperature and moisture has a significant influence on binder performance.

Kantipong and Bahia [9] compared the rutting performance of polymer modified bitumen with conventional bitumen and concluded that the overall performance of the polymer modified binder was better than that found in conventional bitumen.

Huang et al. [4] studied the rheological properties of unaged and aged asphalt-filler mixes and reported that the rheological properties of bitumen depend upon aging and temperatures, and both can be characterized separately 
with the help of different models. Moreover, an increase in aging level corresponds to a decrease in temperature. They developed models that differentiate aging and temperature effects on phase angles.

It is necessary to evaluate the performance of bitumen at various temperatures, states of aging and modification before using the same in the flexible pavements. This study involves the short term aging of three asphalt binders using the rolling thin film oven test (RTFOT), physica smart pave MCR301 and parallel plate test geometry dynamic shear rheometer (DSR). The RTFOT procedure was used to simulate aging during the mixing and placement of asphalt binders. A constant frequency of $10 \mathrm{rad} / \mathrm{sec}$ was selected to ensure that the measurements are within the region of linear behavior.

\section{Objectives}

The objectives of this study were:

1. To determine the rheological parameters of three bitumen types i.e. $60 / 70 \& 40 / 50$ penetration grade bitumen and polymer modified bitumen (PMB) at $25,40,55^{\circ} \mathrm{C}$.

2. To compare rheological parameters of modified bitumen with its base bitumen (60/70) and 40/50 penetration grade bitumen.

3. To study the effects of aging on bitumen that is normally used in Pakistan.

\section{Experimental design}

\subsection{Materials}

Two neat bitumens with penetration grade ' $60 / 70$ ' and ' $40 / 50$ ' and one modified binder (PMB) with base asphalt ' $60 / 70$ ' were used for this study. The bitumen with the penetration grade ' $60 / 70$ ' was modified with $1.6 \%$ Elvaloy ${ }^{\circledR} 4170$ and $0.7 \%$ superphosphoric acid in Attock Refinery, Pakistan. The PG grading of PMB was developed at Mathy Technology and Engineering Services, USA, where in different trials a final blend was prepared that would be more suitable for the climatic conditions. When tested at $76^{\circ} \mathrm{C}$, the final blend produced a Dynamic Shear Rheometer (DSR) value of $1.66 \mathrm{kpa}$ at $16 \mathrm{hrs}$ and $1.3 \mathrm{kpa}$ at 184 hrs after blending as reported in Table 1 [10].

The Australian test specification, test methods and US equivalents used for PMB have been reported in Table 2 [11].

Consistency tests were performed as per AASHTO standards on bitumen in order to determine conventional grading. The results of the consistency tests of PMB matched with the ' $40 / 50$ ' pen. bitumen and hence, both were designated under the same penetration grade. The results of consistency tests have been reported in Table 3 . 
108 Computational Methods and Experiments in Materials Characterisation IV

Table 1: $\quad$ Modification results of ' $60 / 70$ ' penetration grade bitumen with Elvaloy Terpolymer.

\begin{tabular}{|c|c|c|c|c|c|}
\hline Asphalt & Control & $\mathrm{C} 1$ & $\mathrm{D}$ & D1 & $\mathrm{E}$ \\
\hline Penetration grade "60/70" & & $500 \mathrm{~g}$ & $500 \mathrm{~g}$ & $500 \mathrm{~g}$ & $500 \mathrm{~g}$ \\
\hline Elvaloy 4170 & & $1 \%$ & $1.5 \%$ & $1.75 \%$ & $2 \%$ \\
\hline SPA (super phosphoric acid) & & $0.2 \%$ & $0.2 \%$ & $0.2 \%$ & $0.2 \%$ \\
\hline Mix Temperature & & $190^{\circ} \mathrm{C}$ & $190^{\circ} \mathrm{C}$ & $190^{\circ} \mathrm{C}$ & $190^{\circ} \mathrm{C}$ \\
\hline Mix Time & & $3 \mathrm{hrs}$ & $3 \mathrm{hrs}$ & $3 \mathrm{hrs}$ & $3 \mathrm{hrs}$ \\
\hline $\begin{array}{l}\text { Penetration }(\mathrm{dmm}) \text { at } 25^{\circ} \mathrm{C} \\
\text { DSR }\end{array}$ & & 39 & 36 & 42 & 42 \\
\hline $\mathrm{G}^{*} / \sin ($ delta $)$ & 1.9567 & 1.3896 & 1.3443 & 1.103 & 1.7680 \\
\hline Phase Angle & 86.2 & 72.50 & 62.90 & 57.80 & 57 \\
\hline Pass/fail & 63.1 & 73.20 & 79.30 & 83.20 & 82.70 \\
\hline PG Grade & $58 \mathrm{c}$ & $70 \mathrm{c}$ & $76 \mathrm{c}$ & $82 \mathrm{c}$ & $82 c$ \\
\hline Ring \& Ball Softening point & & $141 \mathrm{f} / 60^{\circ}$ & $160 \mathrm{f} / 71$ & $162 \mathrm{f} / 72^{0} \mathrm{C}$ & $169 \mathrm{f} / 76^{0} \mathrm{C}$ \\
\hline $\begin{array}{l}\text { Elastic Recovery } 25^{\circ} \mathrm{C} \\
(20 \mathrm{~cm})\end{array}$ & & $50 \%$ & $72.5 \%$ & $75 \%$ & $78 \%$ \\
\hline Ductility@ $25^{\circ} \mathrm{C}$ & & $37 \mathrm{~cm}$ & $20 \mathrm{~cm}$ & $23 \mathrm{~cm}$ & $22 \mathrm{~cm}$ \\
\hline $\begin{array}{l}\text { Absolute Viscosity } 60^{\circ} \mathrm{C} \\
\text { (poise) }\end{array}$ & & 9107 & 56946 & 112060 & 183474 \\
\hline $\begin{array}{l}\text { Brookfield viscosity } 165^{\circ} \mathrm{C} \\
\text { (centipoises) }\end{array}$ & & 2590 & 4200 & 5040 & 8400 \\
\hline Torsional Recovery (\%) & & 18 & 25 & 32 & 32 \\
\hline
\end{tabular}

Table 2: $\quad$ Specifications limits of PMB.

\begin{tabular}{|c|c|c|c|}
\hline Test Type & $\begin{array}{l}\text { Australian test } \\
\text { Specifications }\end{array}$ & $\begin{array}{l}\text { Australian } \\
\text { Test Methods }\end{array}$ & $\begin{array}{l}\text { US } \\
\text { Equivalent }\end{array}$ \\
\hline $\begin{array}{l}\text { Elastic consistency } @ \\
60^{\circ} \mathrm{C} \text {, pa.s }\end{array}$ & $1500 \mathrm{~min}$ & MBT 21 & Not Known \\
\hline Stiffness@250 C, kpa, & 130 max, & MBT 21 & Not Known \\
\hline $\begin{array}{l}\text { Brookfield Viscosity @ } \\
165^{\circ} \mathrm{C} \text {, pa.s }\end{array}$ & 0.75 max, & MBT 11 & Not Known \\
\hline Flash point ${ }^{0} \mathrm{C}$ & $250 \mathrm{~min}$, & MBT 12 & ASTM D92 \\
\hline $\begin{array}{l}\text { Loss on Heating, \% } \\
\text { Mass }\end{array}$ & $0.6 \max$ & MBT 03 & $\begin{array}{l}\text { ASTM } \\
\text { D1754 }\end{array}$ \\
\hline $\begin{array}{l}\text { Torsional Recovery, @ } \\
25^{\circ} \mathrm{C} \%\end{array}$ & $12 \mathrm{~min}$, & MBT 22 & Not Known \\
\hline Softening point ${ }^{0} \mathrm{C}$ & $60 \mathrm{~min}$, & MBT 31 & ASTM D36 \\
\hline
\end{tabular}


Table 3: $\quad$ Consistency of bitumen results.

\begin{tabular}{|c|c|c|c|c|}
\hline \multirow{3}{*}{$\begin{array}{l}\text { Test } \\
\text { Description }\end{array}$} & \multirow{3}{*}{$\begin{array}{l}\text { Test } \\
\text { Methods }\end{array}$} & \multicolumn{3}{|c|}{ Results and specifications } \\
\hline & & \multirow[b]{2}{*}{ PMB } & \multicolumn{2}{|c|}{ AASHTO M-20 } \\
\hline & & & $\begin{array}{l}60 / 70 \\
\text { grade }\end{array}$ & $\begin{array}{l}40 / 50 \\
\text { grade }\end{array}$ \\
\hline Ductility@ & AASHTO & 45 & 100 & 67 \\
\hline $25^{\circ} \mathrm{C}(\mathrm{cm})$ & D113 & & $\begin{array}{l}(100- \\
\text { minimum })\end{array}$ & $\begin{array}{l}(100- \\
\text { minimum) }\end{array}$ \\
\hline Flash Point, & AASHTO & $>232$ & $>232$ & $>232$ \\
\hline $\mathrm{COC}\left({ }^{\circ} \mathrm{C}\left({ }^{\circ} \mathrm{F}\right)\right)$ & D92 & & $\begin{array}{l}(232- \\
\text { minimum) }\end{array}$ & $\begin{array}{l}(232- \\
\text { minimum) }\end{array}$ \\
\hline Penetration@ & AASHTO & 46 & $65(60-70)$ & $44(40-50)$ \\
\hline $\begin{array}{l}25^{\circ} \mathrm{C}(1 / 10 \\
\mathrm{mm})\end{array}$ & D5 & & & \\
\hline Softening Point & $\begin{array}{l}\text { AASHTO D } \\
36\end{array}$ & 58 & $\begin{array}{l}49 \\
(50-\text { minimum })\end{array}$ & $\begin{array}{l}56 \\
(60- \\
\text { minimum })\end{array}$ \\
\hline
\end{tabular}

\section{Testing}

Short term aging using RTFOT was carried out as per ASTM D 2872-97, which covers the determination of the effect of heat and air on a film of asphaltic materials. A total mass of $35 \pm 0.1 \mathrm{~g}$ of a thin bitumen film was taken in a standardized bottle during this test and exposed to airflow at a rate of $4000 \pm 200$ $\mathrm{ml} / \mathrm{min}$, for 85 minutes, and at a constant temperature of $163 \pm 0.5^{\circ} \mathrm{C}$. The residue from the bottle was then collected and homogenized.

The effects before and after this treatment were determined using DSR, which is capable of characterizing the viscous and elastic behavior of bitumen at low, medium, and high temperatures, which are anticipated in the area where the asphalt binder would have been used. Eighteen specimens (both aged and unaged) were tested, i.e. three specimens from each bitumen type. Specimens were prepared using the standard test methods for "Determining the Rheological properties of Asphalt Binders using a Dynamic Shear Rheometer" ASTM D 7175-08. The test specimens were maintained at the test temperature within $\pm 0.1^{0} \mathrm{C}$ by heating and cooling the upper and lower plates.

\section{Results and discussion}

Bitumen is characterized by the time of loading, temperature and the dependency of the mechanical response to loading [12]. Bituminous binder aging may be caused by different factors, but the key component of concern for the RTFOT is the loss of volatiles. The loss of smaller molecules was observed to cause an increase in bitumen viscosity. This can best be simulated with the loss of volatiles in the binder during its manufacturing and placement process. The elevated temperature of this process ages the bitumen by driving off a substantial 
amount of volatiles. The principal viscoelastic parameters determined for aged and unaged bitumen have been compared in Table 4 and shown graphically in Figures 1(a), 1(b), 2(a) and 2(b).

It can be seen from Figures 1(a), 1(b), 2(a) and 2(b) that the rheological properties of asphalt binders depend on the temperature and aging with RTFOT. The complex modulus decreases drastically with an increase in temperature, which may cause an increase in binder susceptibility to rut. The phase angle increases with the increase in temperature at a given frequency, resulting in the delayed response of the binder at high temperatures. The phase angle and complex modulus were further compared at three temperature conditions as shown in Figures 3 and 4. It was observed that with the increase in the phase angle, the complex modulus or the stiffness of binder reduces in both aged and unaged specimens.

Table 4: Comparison of rheological parameters for unaged and aged samples.

\begin{tabular}{|c|c|c|c|c|c|}
\hline \multirow{2}{*}{$\begin{array}{l}\text { Bitumen } \\
\text { Types }\end{array}$} & \multirow{2}{*}{$\begin{array}{l}\text { Temperature } \\
\quad\left({ }^{\circ} \mathrm{C}\right)\end{array}$} & \multicolumn{2}{|c|}{$\begin{array}{l}\text { Phase Angle } \\
\left(\varnothing^{\circ}\right)\end{array}$} & \multicolumn{2}{|c|}{$\begin{array}{l}\text { Mean Complex Modulus }\left(\mathrm{G}^{*}\right) \\
\qquad(\mathrm{kPa})\end{array}$} \\
\hline & & Un-aged & $\begin{array}{l}\text { Aged on } \\
\text { RTFO }\end{array}$ & Un-aged & $\begin{array}{ll}\text { Aged } & \text { on } \\
\text { RTFOT } & \\
\end{array}$ \\
\hline \multirow{3}{*}{$60-70$} & 25 & 72.5 & 59.5 & 462 & 591 \\
\hline & 40 & 80.8 & 61.4 & 37 & 47 \\
\hline & 55 & 86.6 & 63.2 & 3 & 4 \\
\hline \multirow{3}{*}{$40-50$} & 25 & 74.7 & 63.5 & 995 & 1323 \\
\hline & 40 & 83.8 & 65.4 & 75 & 95 \\
\hline & 55 & 87.7 & 66.7 & 6 & 7 \\
\hline \multirow{3}{*}{ PMB } & 25 & 66.9 & 58.2 & 875 & 1138 \\
\hline & 40 & 69.8 & 56.5 & 60 & 77 \\
\hline & 55 & 70.7 & 55.1 & 7 & 9 \\
\hline
\end{tabular}

\section{Conclusion}

Based on the results obtained in this research study, the following conclusions can be drawn;

- The complex shear modulus of binders reduces significantly with an increase in temperature, while the phase angle increases, but at a lesser rate.

- Short term aging influences relatively lesser on binder rheology than temperature. 
- Bitumen with a ' $60 / 70$ ' penetration grade was observed to be more sensitive to temperature and short term aging than other binders. At the same time, PMB was observed to be the least sensitive binder.

- Bitumen '60/70' pen. grade, modified with Elvaloy Terpolymer, showed better rheological parameters than '40/50' pen. grade under specified test conditions.

Un-aged specimen results

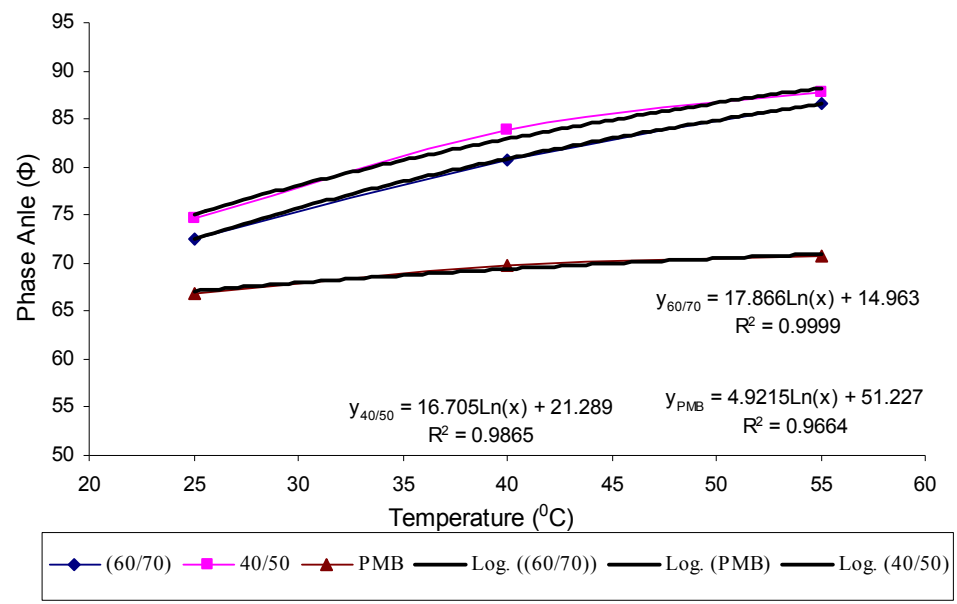

(a)

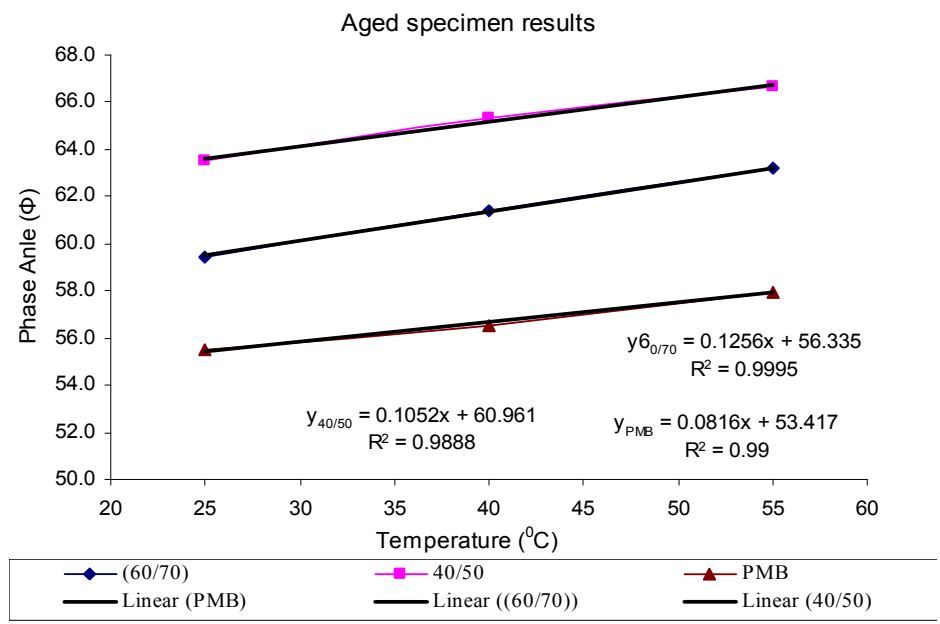

(b)

Figure 1: (a) Influence of temperature on phase angle (unaged specimens).

(b) Influence of temperature on phase angle (aged specimens). 
112 Computational Methods and Experiments in Materials Characterisation IV

Un-aged specimen results

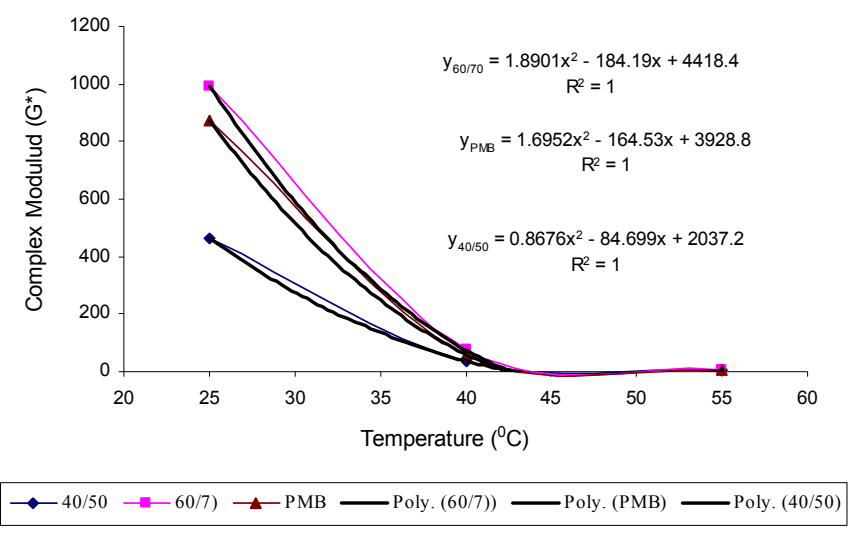

(a)

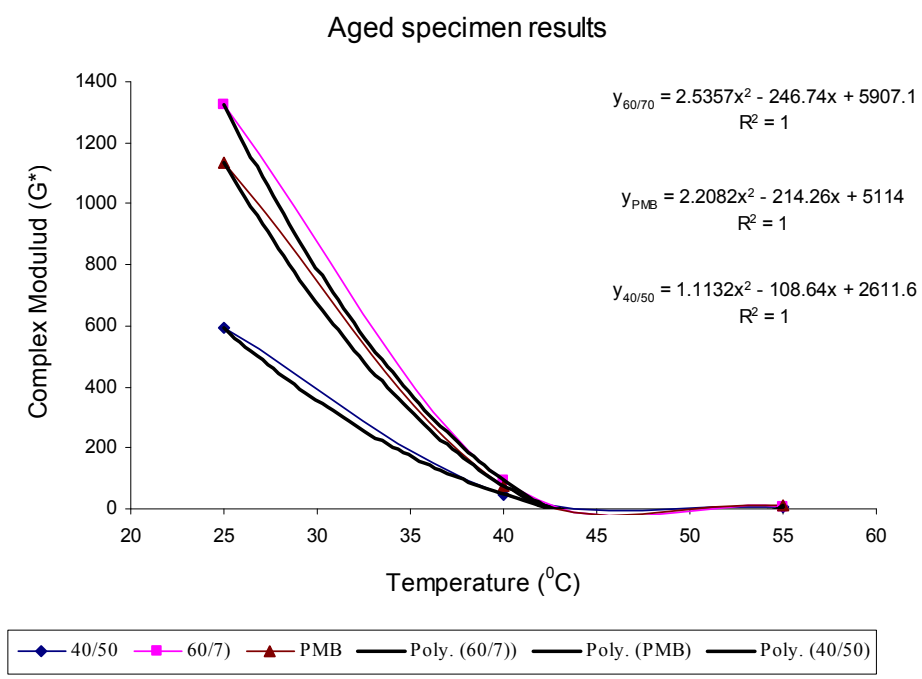

(b)

Figure 2: (a) Influence of temperature on complex modulus (unaged specimens). (b) Influence of temperature on complex modulus (aged specimens). 


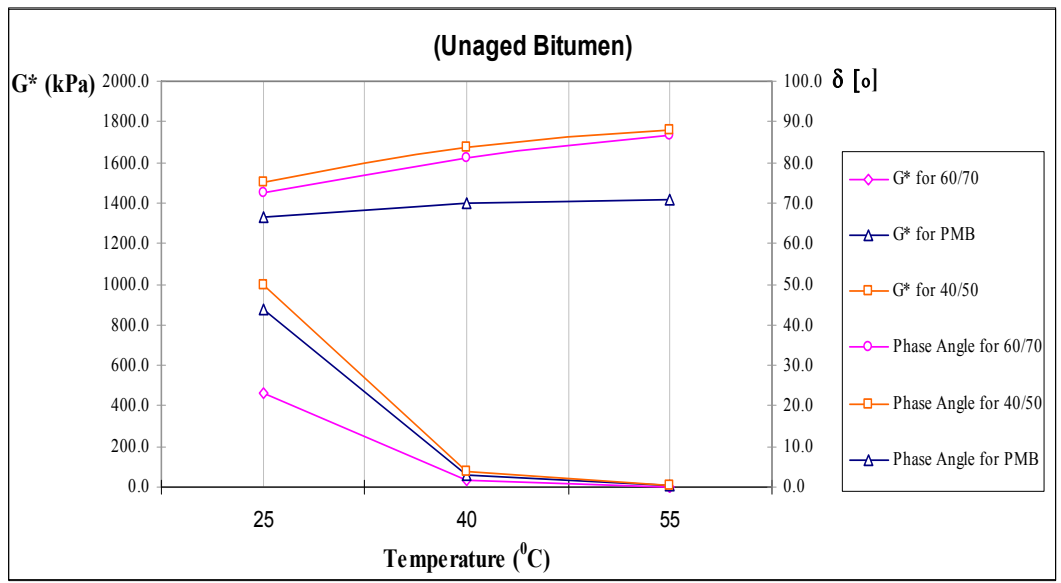

Figure 3: Variation in phase angle and complex modulus with temperature in aged bitumen.

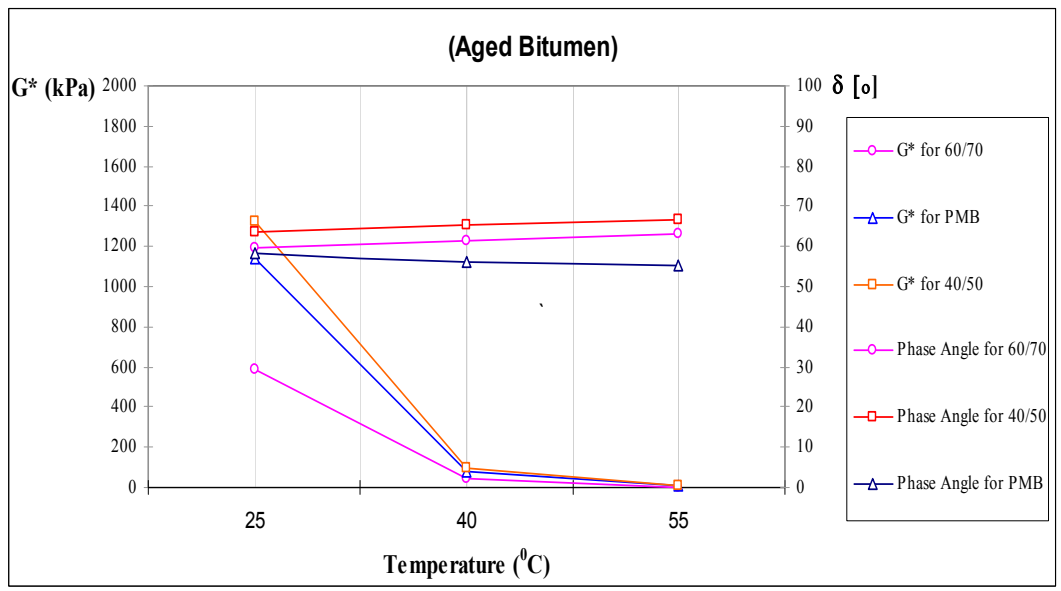

Figure 4: Variation in phase angle and complex modulus with temperature in unaged bitumen.

\section{References}

[1] Imran Hafeez, Kamal M. A., "Accidents Black Spots on highways and their low cost remedial measures." Proceedings of $14^{\text {th }}$ International conference on Urban Transportation and the Environmental in the $21^{\text {st }}$ Century", $1-3^{\text {rd }}$ September 2008, Malta, pp 691-700

[2] Thomase G. Mezger, "The Rheology Handbook” pp13, 2002 
[3] Barnes H.A., J.F. Hulton and K. Walters, "Introduction to rheology". Elsevier, Barking 1989.

[4] Huang, Shin-Che and Zeng Menglan, "Characterization of aging effect on rheological properties of asphalt-filler systems", International Journal of Pavement Engineering, 8:3, 213-223, 2007.

[5] Asphalt Institute "Performance Graded Asphalt Binder Specification and Testing” Superpave Series No. 1(SP-1), $3^{\text {rd }}$ Edition (Revised), 2003.

[6] Branthaver, J.F., Peterson, J.C., Robertson, R.E., Duvall J.J., Kim, S.S., Harnsberger, P.M., Mill, T., Barbour, F.A., and Scharbron, J.F., "Binder Characterization and Evaluation", Volume 2: Chemistry. SHRP-A-368, 1993.

[7] Robert N. Hunter. "Asphalt in roads construction" American Society of Civil Engineering, Thomas Telford Publications, pp 75, London, June 2000.

[8] Tarefder, R.A., Zaman, M., Hobson, K., A Laboratory and statistical evaluation of factors affecting rutting, International Journal of Pavement Engineering. Volume 4 Number 1, 59-68.2003.

[9] Kanitpong, K., Bahia, H., Relating adhesion and cohesion of asphalts to the effect of moisture on laboratory performance of asphalt mixtures, Transportation Research Record, 1901, 33-43. 2005.

[10] Gerald Reinke, Elvaloy Formulation with Attock Asphalt. Mathy Technology \& Engineering Services, Inc, Wisconsin, USA, 2001.

[11] Kamal M. A, Imran Hafeez, "Time Dependant Volumetric Behavior of Flexible Pavement under Heavy Loading \& High Temperature" Proceedings of $1^{\text {st }}$ International conference on Transportation Geotechnics, $25-27^{\text {th }}$ august 2008, University of Nottingham, UK, "Advances in Geotechnics" pp523-527

[12] Burger A.F., Van de Van M.F.C, J. Muller, K.J. Jenkins., "Rheology of Polymer Modified Bitumen: A Comparison Study of Three Binders and Three Binder/Filler Systems", $20^{\text {th }}$ South African Transport Conference, Meeting the Transport Challenges in Southern Africa, 16-20 July, 2001. 